\title{
UIT HET VOLKSLEVEN VAN DE BEWONERS DER HUMBOLDTSBAAI.
}

\author{
DOOR \\ F J. F. VAN HASSELT. \\ Zendeling der U. Z. V.
}

Als Mr. H. A. Lorentz in zijn werk: Eenige maanden onder de Papoea's mededeelt, dat hij en de medeleden der Wichmann expeditie ondanks al hun vragen en onderzoeken, niets definitiefs hebben te weten kumnen komen omtrent den godsdienst der bewoners van de Humboldts-Baai, dan bevestigt hij daarmede de ervaring van velen, die op 't punt van godsdienst den inboorling zcer gesloten vinden. Mr. L. verklaart dit uit wantrouwen jegens den Europeaan, ook acht hij 't zeer goed mogelijk dat de inboorlingen het niet noodig vinden dat de Europeanen de beteekenis van dat alles te weten komen. En ten derde meent hij dat ze zelve de ceremoniën niet meer weten, omdat o. a. ze ook liederen zingeu, die ze niet begrijpen. ${ }^{1}$

Prof. Max Muller wijst ook op dit verschijnsel ${ }^{2}$ en zegt: Velen wilden hebben een afkeer van vragen over godsdienstige punten, deels misschien uit bijgeloovige vrees, deels misschien ten gevolge hunner oubeholpenheid, om hunue onafgewerkte gedachten en gevoelens in bepaalde taal te uiten. Hij wijst verder op het gevaarlijke om dadelijk eene conclusie te trekken uit hetgeen men verneemt of niet verneemt. Als voorbeeld halt Prof. M. M. dan aan, hoe eenige uitnemende Benedictijner missionarissen, na drie jaren op hun post in Australië te hebben doorgebracht, tot de conclusie waren gekomen, dat de inboorlingen hoegenaamd geene godheid, waar of valsch, aanbaden. Later echter bemerkten zij, dat de inboorlingen in een almachtig Wezen geloofden, dat de wereld geschapen had. ${ }^{3}$

1 Mr. H. Lorentz. Eenige maanden onder de Papoea's. blz. 36, 37.

2 Max Muller. Oorsprong en ontwikkeling van den Godsdienst blz. 90.

3 t. a. p. blz. 91. 
't Gaat met het onderzoek naar den godsdienst al gelijk als met 't onderzoek naar de taal. 't Gebeurt, dat meu naar een woord zoekt, de zaak uitduidt die men bedoelt, synoniemen gebruikt, en men hoort 't niet, tot men eensklaps als 't ware den inboorling attrapeert op 't gebruik van bedoeld woorl. En toch schuilt er geen onwelwillendheid in dit onwillekeurig achterhouden.

'Zoo is 't ook in religieuse zaken. Hunue van de ouden overgeleverde ceremoniën te verklaren, kumnen ze niet, zc doen er geen moeite voor. De godsdicnst is versteend. 't Hoort er nu eenmaal bij, doet men 't niet dan zijn hier de voorouders, ginds de Groote Geest, dáár de Heer des hemels boos.

't Deed me daarom genoegen, gedurende een kort verblijf aan de Humboldtsbaai, ecne uiting van religieus voelen te kunnen gadeslaan, geen godsvercering of afgodendienst, maar toch een blijk van geloof, éen voortbestaan der zicl, een trek van animisme.

Gaarne wil ik U mededeelen hetgeen ik zag en hoorde, en ik noodig $\mathrm{U}$ uit in den geest me te volgen naar Tobadi, de toouaangevende, meestbeteekenende kampoug aan de Humboldts Baai.

Van het eilandje Meto Débi laten we ons roeien naar bedoeld dorp, welks huizen alle op het water stann. Een eigenaardig gezicht is het al die hooge, spits toeloopende dakeu. Naderbij komende zien we, dat op de punt van vele dakeu poppen zijn geplaatst. Dezc poppen $\pm 1 \mathrm{M}$. hoog worden gesnedeu uit het onderste gedeelte van den stam-varen, en met de aarde om den wortel boven op het huis bevestigd. Deze beelden moeten de negorij tegen brand en ander leed behoeden. Verscheidene dragen in den hollen kop een orchidee, wardoor 't op een afstaud schijnt of het hoofd behaard is.

Ondertusschen zijn we het doel van den tocht genaderd, de Karrewari, 't verblijf der jongelieden. Voor de Karrewari is een groot plankier, waarop tijdens de feesten de dansen worden uitgevoerd.

We vragen naar den Korano. Men wijst ous naar een groot huis in de onmiddellijke nabijheid van de Karrewari. Daar binnen is het opperhoofd, hij is ziek. Maar we kunnen toch wel binnen komen. We treden een zcer ruim verblijf binnen. 't Is er echter donker en rookerig. In een hoek van 't huis brandt een groot vuur. Daar moet de Korano te vinden zijn. Omringd door zijne vrouwen en familieleden vinden we voor 't vuur gezeten een man van \pm 4.0 jaren. 
Sinds we hem eene week geleden zijne opwachting zagen maken bij den ass. res., is hij veel vermagerd; toch is dat gelaat, nu beschenen door den rossen gloed van het hoog-opflikkerende vuur, niet lcelijk; integendeel, voor 'n Papoea vrij knap. Hij zit voorover, turende naar de vlam, tot hij met een forschen ruk zich achterover werpt, waar middels rollen geklopt boomschors cen rustbed voor hem is bereid. Sommigen uit de omgeving wrijven hem op den buik, een ander strijkt hem liefkozend met de hand over ' $t$ hoofd. De zieke klaagt over hoofdpijn en pijn in de lendenen, dat is verdacht, zeer verdacht gedurcnde eene pokkcnepidemie, en werkelijk bij nadere beschouwing zijn de teekenen der gevrecsde ziekte reeds merkbaar.

We kunnen raad geven, meer niet, hoe 't best te handelen.

We gaan weer heen, blij de benauwde atmosfeer te kunnen verlaten. Buiten staan heel wat menschen. Zoo juist zijn ze teruggekomen van een groot feest te Skow, de haren versierd met helroode bloemen of witte en grijze veeren, de angezichten geheel of gedeeltelijk zwart geverfd; sommigen kleurden nog de oogleden rood. Vooral schrikwekkend ziet er de "dokter" uit, z. a. de tolk hem voorgesteld heeft. 't Is de man, die kruiden geeft tegen krankheid, maar die ook medicijn geeft om zich onzichtbaar te maken bij 't plegen van een moord.

De stemming is wat gedrukt. 't Bericht is vernomen, dat, wat eenige dagen gevreesd werd, werkclijkheid is - de Korano heeft de ziekte.

De Korano! Dit woord (Kolano) is van elders overgenomen kòrosari is de titel in de eigen taal. De Korano! We zijn op Nieuw-Guinea gewend, dat de hoofden, zij 't, dat ze Korano heeten, of Singhadji of Majoor of hoe dan ook, bitter weinig macht hebben. Eene uitzondering maakt echter de Karano van Jotofa (Tobadi en eenige andere plaatsen). De heer G. L. Bink, die in 1892 drie maanden an de Humboldts-Baai doorbracht, mankte reeds gewag van de groote macht, dic de vader van dezen Korano toonde te bezitten. Zoo veel had déze Korano wel niet te zeggen - (de ouden, zijne ooms enz. hadden daartoe te veel invloed) maar toch was zijne macht niet gering.

Alleen op zijn bevel mocht de bevolking gaan visschen, en dan moest de visch nog alle bij hem gebracht worden, en hij verdeelde den buit, naar 't hern goed dacht. Ook de tuinvruchten moesten bij hem gebracht worden, hij gaf weer uit, naar hem beliefde. Als 
hij 't beval, mocht niemand klappers plukken. ${ }^{1}$ ) Had iemand twee prauwen, dan liet hij er cen vernietigen, hij wilde niet, dat iemand meer dan ééne prauw had.

Toch was 't hem niet genoeg zooveel te outvangen van zijn volk, hij ontzag zich niet om bij de handelaars op Meto Débi te gaan bedelen om tabak. "Onze Korano", zoo zei me de tolk, "is niet als audere opperhoofden, onze Korano bestaat zoolang de wereld bestaat". (Hij bedoelde 't Korano-schap).

Toch toonde geen uiterlijk kenteeken zijne macht. Hij vertoonde zich immer zonder cenig gewaad, uitgenomen een lapje van \pm 3 d.M. ${ }^{2}$., dat hij zich vóórgebonden had. Hier gold dus niet: "De kleeren maken den man!"

Eerst scheen het, of de ziekte een gunstigen keer nam; maar toen ook mond- en keelholte werden aangedaan, nam de ziekte telkens toe, tot we in den nacht van den $25^{\text {en }}$ op $26^{\text {en }}$ Aug. opgeschrikt werden door het geschrei, dat van Tobadi opsteeg. De Korano was dus dood. 's Middags was reeds eene deputatie van eenige ouden van dagen bij den posthouder geweest met de boodschap, dat de Korano lag te sterven en als hij dood ging dan moest er naar oude adat iemand van een naburigen stam gedood worden. De posthouder verbood dit ten strengste, en ze beloofden zich naar zijn verbod te schikkev.

Tot mijn verbazing ${ }^{2}$ ) klonken in den morgen gecue klaagtoonen meer van Tobadi. Integendeel, we vernamen gezang en we zagen mannen en vrouwen dansen op het plankier van de karrewari. Ik liet er mij heenbrengen, en ik kwam juist toen het de beurt der vrouwen was. In gesloten gelederen marcheerden ze al zingende over bedoeld plankier - plots hielden ze zich stil, stonden dan op ééne plaats te zingen en te trappelen, maakte dan weer eene wending, de groep splitste zich dan weer in twee deelen. Daar was niemand die dirigeerde en toch scheen alles op commando te gaan. Alleen waren twee oude vrouwen bijzonder in actie. Ze zwaaiden met een lang stuk geklopte boomschors, manoeuvreerden met armen en bovenlijf, dansten samen of soms met den gansche groep.

Alle deelneemsters aan den dans waren gekleed met een sarong

1 Mr. H. Lorentz. Eenige maanden onder de Papoea's, Blz. 19.

2 De heer Alb. C. Kruyt verhaalt in "Het Animisme in den Ind. Arch." blz. 272 dat ook in Angkola juist zeer veel gespeeld en pret gemaakt wordt zoolang het lijk boven aarde staat. 
van geklopte boomschors, zeer donker van kleur, met een band om de heupen vastgehouden. Onder de jongeren was een enkele met een gekleurde katoenen sarong; vreemd stond in deze groep de weduwe van een handelaar, gekleed in bonte kabaai cn kleurige sarong.

Sieraden in overvloed, aan armen, neus, ooren, om den hals, over de borst. Beenen, rug, borst en aangezicht dikwijls getatoueerd of voorzien van breede litteekenen, nagebleven van wonden, expres gebrand of gestoken om het latere litteeken.

Vóór het sterfhuis zitten de maunen vergaderd. Evenmin als de vrouwen toonen zij eenig blijk van droefheid. Hunne andacht is bepaald bij eenige armbanden, die op den vloer liggen. De tolk roept mij, toont me de armbanden, en vraagt of ik zulke armbanden al meer gezien heb. Neen, ik kon gerust verklaren, dat ik zoo iets dergelijks nog nimmer gezien had. Groote donker-groene en okerkleurige armbanden, waarschijnlijk in den Compagnie's tijd op de eene of andere wijze in het bezit der voorouders gekomcu. De tegenwoordige Tobadiërs verklaren 't echter als fabrikat van hunne voorvaderen - zij kennen echter 't geheim der vervaardiging niet meer.

In 't geheel waren er 16, alle gewikkeld in boombast. Sommige vrouwen droegen als borstsieraad eenige armbanden, doch ingewikkeld. De Korano droeg er twee, wanneer hij op reis ging. Deze behoedden hem tegen pijlen van vijanden, de overige echter moesten thuis blijveu. Nu na den dood van den Korano werden ze bezichtigd en geteld. Iedere armband had een naam en eene geschiedenis. Men vertelde elkander de historie der armbanden, hoe déze door het naburige Skow als oorlogsschatting was betaald, hoe gene door Nafri was opgebracht, enz. ')

Naar de armbanden kijkende, vroeg ik, wie nu Korano zou worden, want het kind van den Korano was toch nog te klein. Men meende echter, dat deze Korano moest worden onder voogdijschap der ouders, "want aan het kind gingen de armbanden over, dus het kind was Korano"!! ${ }^{1}$ )

$1 \mathrm{Mr}$. Lorentz. teekent omtrent deze armbanden aan,t. a. p. blz. 29, „De grootste schat zijn de z. g. n. "khās;" deze doen denken aan armbanden vervaardigd uit de ziel van een oude flesch van groen glas. Zijn de sěmbõnis gewoonlijk particulier eigendom, de khās behooren tot het vermogen van de gemeenschap. $\mathrm{Zij}$ worden gebruikt, indien er om de een of andere reden eene schatting aan een andere kampong moet betaald worden.

2 Ook van elders is bekend, dat hem die de rijkssieraden bezit, het gezag toekomt. 
Toch schijnt men van gevocleu veranderd te zijn, want den volgenden dag werd toch de jougere broeder in de plaats vau den doode gekozen.

De dans der vrouwen was intusschen gëeindigd. Ze verdwenen, vermocid van inspanning en glimmend van het zwect in hare respective huizen.

Des middags was ik door vaccinatic-arbeid verhinderd naar Tobadi te gaan. Van Meto Débi uit konden we echter zien, hoe het dansen bijna onafgebroken voortging.

Ook zagen we, hoe van verschillende kauten prauwen kwamen met klappers eu aardvruchten, die alle naar Tobadi gevoerd werden. Een enkele maal kwam er ook eene prauw aan, waarin een der roeiers met zijn roeispaan het water hoog opspatte. Dat was 'n teeken, dat die prauw een varken bracht voor het offermaal.

Ook den tweeden dag begomnen de zangen en de reien opnieuw.

In den middag kwam er eene uitnoodiging tot den posthouder om de verkiezing van een nieuwen Korano bij te wouen. Dit zou gebeuren onmiddellijk na de bijzetting van het lijk des gestorvenen. We besloten allen te gaan.

Circa 4 uur zagen we cen grooten stoet per prauwen Tobadi verlaten met zich voerende het lijk van den Korano. Dit was in matten gewikkeld.

Met bracht het naar een klein rots-eilandje in de buurt, waarheen alle dooden vau Tobadi gebracht werden. Men begraft de lijken niet, men plaatst ze op stellaadjes of in de boomen. Daar laat men de lijken tot alle vleesch verteerd is. Daarua vergadert men de beenderen, pakt die weder in en laat deze op de stelling.

Één onzer meende opgemerkt te hebbeu, dat vrouwen het lijk ten grave droegen.

We kwamen te Tobadi aan vóór de stoet terug was. We vonden het plankier thaus geheel ingenomen door \pm 2000 klappers, hoopen aardvruchten, de stukken vain vijf geslachte varkeus, 20 bossen pisang enz.

Toen de bevolkiug "weergekeerd was van de drocve plechtigheid" (heel veel indruk scheen 't niet gemaakt te hebben), zette een groep zich neder aan den buitenkant van het plankier, anderen bewogen zich tusschen het opgestapelde voedsel, weer anderen, vooral die eenig Maleisch spraken, trachtten zich zoo goed het kon met ons en met de mede-aanwezige handelars te onderhouden, gaven gaarne gevraggde inlichtingen. Eensklaps hoorden we een luiden, zangerigen 
uitroep. Eén onzer meende, dat we een solo te hooren zouden krijgen 't bleek echter wat anders. Nauwelijks hoorde men dien roep, of alles zette zich neder, ook ons werd beduid, dat we moesten gaan zitten.

Aan de zeezijde van het plaukier, op het uiterste puntje, zagen we nu een grijsaard zitten, het aangezicht gekeerd naar het rotseilandje, waar de dooden rusten.

Den tolk, dic nasst mij zat, vroeg $\mathrm{ik}$, wat dat beduidde.

"De grijsaard roept den geest van den Korano op."

$\mathrm{Na}$ den lang-gerekten, zangerigen oproep, een oogenblik stilte. Men kon een speld hooren vallen.

Toen hoorden we den oude prateu op gewonen toon. "Wat zegt hij nu!" "Hij zegt, dat nu de Korano dood is, hij niet boos moet zijn, dat ze eene nieuwen Korano verkiezen zullen." Toen weer de oproep van zoo even. Weer stilte! En toen: "Wees niet boos, we hebben vijf varkens geslacht." Daarna weer de oproep. En toen: "Wees niet boos, we hebben drie of vier duizend klappers!" En zoo gaat het voort. Een oproep - en dan eene opsomming van hetgeen bijecugezameld is. Daarop eene pauze van eenige minuten. Toeı keert de oude zich tot de verzamelde menigte, een glimlach op 't gelaat. Hij makt eene beweging met de hand en zegt, dat het $\mathrm{nu}$ in orde is, de Korano is niet boos.

$\mathrm{Nu}$ rijst een groep jongelui op en een oorverdoovend gejubel weerklinkt van hunne lippen. Opwekkend is de zang, warmede ze hun dans, eigenlijk meer hun voetgetrappel begeleiden. Geen commando weerklonk, geen dirigent die den zang leidt, 't lijkt alles spontaan.

't Meest van alles verbaasde me hast de orde, de regelmaat, waarmede alles werd uitgevoerd, alsof 't dagelijksch werk was Korano's te funereeren.

$\mathrm{Nu}$ kwam de jongere broeder voor den dag op wien, naar de keuze der gemeenschap de waardigheid van Korano over zou gaan.

De posthouder liet hem mildels den tolk beloven zich te voegen naar de bevelen der "Kompanie" en geen bloed meer te zullen laten vergieten.

Met de Nederlandsche vlag in de hand, beloofde de nieuwe waardigheidsbekleeder zulks. Drie salvo's weerklonken uit de geweren der politiedienaren, door den posthouder meegebracht.

Dat schieten wekte ontroering, blijkende uit het klagelijk geschrei, dat in sommige huizen klonk. 
De plechtigheid was afgeloopen, de uitdeeling der spijzen begon. De stamgenooteu van den Korano namen zelve niets, doch de belangstellenden, uit de andere dorpen, en de vreemde elementen in eigen kampong ontvingen ieder hun deel; ook de Chineesche en Maleische handelaars ontvingen 't een en ander, den posthouder werd een varkenspoot vereerd.

In een oogwenk was 't platform leeg.

Den volgenden dag begon de eigenlijke rouw, de groote haarbossen werden heel wat ingekort, sommigen lieten zich het hoofd kaal scheren. Ze hadden daardoor veel last van de zonnehitte een Chinees, ruim voorzien van breed-gerande stroohoeden deed goede zaken.

De sieraden werden opgeborgen tot nader order.

Als de nieuwe Korano 't groote doodenmaal ter ecre van zijnen broeder geven zal, dan is de rouw opgeheven, doch dat kan nog wel twee of drie jaren duren.

'k Gaf het bovenvermelde, z. a. ik 't waarnam, zonder conclusie's er uit te trekken of commentaren te maken.

Boeken, als b. v. Kruyt's "Animisme" werpen veel licht over dergelijke gebruiken. Wie eene verklaring zoekt voor hetgeen hem vreemd is, kan dáár terecht.

Mausinam (Noord Nieuw-Guinea). Sept. 1908. 